\title{
Dietary breadth and trophic position of introduced European catfish Silurus glanis in the River Tarn (Garonne River basin), southwest France
}

\author{
J. Syväranta ${ }^{1,3, *}$, J. Cucherousset ${ }^{1,4}$, D. Kopp ${ }^{1,5}$, A. Crivelli' ${ }^{2}$, R. Céréghino ${ }^{1}$, \\ F. Santoul ${ }^{1}$ \\ ${ }^{1}$ EcoLab, UMR 5245 (CNRS-UPS-INPT), Université de Toulouse, bât 4R3, 118, route de Narbonne, \\ 31062 Toulouse Cedex 9, France \\ ${ }^{2}$ Station biologique de la Tour du Valat, Le Sambuc, 13200 Arles, France \\ ${ }^{3}$ Present address: Department of Biological and Environmental Science, PL35, 40014 University of Jyväskylä, Finland \\ ${ }^{4}$ Present address: Centre for Conservation Ecology and Environmental Change, School of Conservation Sciences, \\ Bournemouth University, Poole, Dorset BH12 5BB, UK \\ ${ }^{5}$ Present address: IFREMER, Equipe Ecologie et Modéles pour l'Halieutique, Rue de l'Ile d'Yeu, BP 21105, \\ 44311 Nantes Cedex 3, France
}

\begin{abstract}
Although being a widely introduced and successfully established species, the European catfish Silurus glanis L. (the world's third largest freshwater fish) remains poorly studied in its introduced areas. Here we studied the trophic ecology of non-native European catfish in a large river system in south-western France using stomach content and stable isotope analyses (SIA). We used fin samples for SIA of catfish and hence tested the validity of using fin tissue as a proxy for muscle in SIA. The mean $\delta^{15} \mathrm{~N}$ and $\delta^{13} \mathrm{C}$ values analysed from fin tissues did not differ from those analysed from muscle tissue and reflected strong and consistent relationships $\left(\mathrm{r}^{2}=0.95\right.$ for carbon and $\mathrm{r}^{2}=0.98$ for nitrogen). The $\delta^{15} \mathrm{~N}$ values varied almost $5 \%$ among the analysed catfish individuals, while $\delta^{13} \mathrm{C}$ values varied $>5 \%$. Total length of these catfish ranged from 200 to $2240 \mathrm{~mm}$ and was correlated with $\delta^{15} \mathrm{~N}$ and especially with $\delta^{13} \mathrm{C}$ values. Although catfish length and $\delta^{15} \mathrm{~N}$ values were positively correlated, the mean trophic positions of catfish increased only slightly from smaller individuals to larger ones (4.3 to 4.7). However, larger catfish were considerably ${ }^{13} \mathrm{C}$-enriched in their $\delta^{13} \mathrm{C}$ values compared to smaller individuals and had up to $4 \%$ higher $\delta^{13} \mathrm{C}$ values than their expected aquatic prey. This might indicate frequent consumption of mammals and/or non-aquatic birds by the larger sized individuals, which were found in the catfish stomachs.
\end{abstract}

KEY WORDS: Stable isotopes $\cdot$ Introduced species $\cdot$ Top predator $\cdot$ River $\cdot$ Food web $\cdot$ Fin clips

\section{INTRODUCTION}

Fishes are among the most frequently introduced freshwater organisms (Copp et al. 2005), and fish invasions are recognised as a serious threat to freshwater ecosystems (Dudgeon et al. 2006). Introduced predatory fish species can have important implications for native species and food webs (Vander Zanden et al. 1999, Eby et al. 2006). Large-bodied predators (i.e. larger than typical native predators) can destabilise natural communities by occupying the highest trophic position and introducing a new predatory pressure on lower trophic levels. Indeed, body size typically plays an important role in determining trophic positions (Cohen et al. 1993, Roy et al. 2002, Woodward et al. 2005, but see also Layman et al. 2005) due to morphological constraints in feeding related to limited gape size of predators (Cohen et al. 1993, Forsman 1996). 
European catfish Silurus glanis L (hereafter catfish) is the world's third largest (and the largest European) species (Stone 2007). Native to eastern Europe and western Asia, catfish has been widely introduced outside its native range due to its popularity as a sport fish and in aquaculture (Copp et al. 2009), making catfish an intriguing model to study the trophic ecology of large-bodied, non-native top predators. The species has now established self-sustained populations in many countries of western Europe. A recent review of the environmental biology of catfish by Copp et al. (2009) identified a serious lack of knowledge concerning this species, particularly in its introduced range and in riverine ecosystems. Such information is often a prerequisite for assessing potential risks to native species and ecosystems in areas where non-native species are established. The ecology of catfish outside its native range and interactions with native biota are poorly known, and this is especially true for the larger individuals (i.e. $>1 \mathrm{~m}_{\text {; }}$ Wysujack \& Mehner 2005, Carol 2007). In its introduced areas, adult catfish can be at least twice as large as the native piscivorous fishes, but its precise position in the food web and potential impacts on other species are not thoroughly understood. In the few published studies, catfish have been reported to be a poor biomanipulator species (Wysujack \& Mehner 2005), having only vague top-down impacts on the underlying fish community. But in areas with only a few or no native predatory fish species (such as in Spain), introduced catfish have had strong adverse impacts on the native fish community (Copp et al. 2009). Considering the low number of published studies on catfish trophic ecology, the practical and technical difficulties in studying these large-bodied species are no wonder, especially in large riverine ecosystems.

Stable isotope analysis (SIA) has been identified as a potentially valuable tool in studies on introductions of non-native species (e.g. Vander Zanden et al. 1999, 2004, Gorokhova et al. 2005, Cucherousset et al. 2007, Olsson et al. 2009), potentially including those examining the trophic position of catfish (Copp et al. 2009). The aim of the present study was to assess the validity of SIA to study the trophic ecology of catfish and then to assess the trophic position of introduced catfish within the food web of a large river in southwestern France. Our specific objectives were to: (1) compare stable isotope values from muscle and fin tissues to assess the suitability of fin material as a non-lethal proxy for muscle, (2) assess the trophic position and potential ontogenetic changes in trophic position of the catfish using both SIA and stomach contents, and (3) evaluate the potential impact of European catfish on the recipient food web. This should help in evaluating their potential ecological impacts on the ecosystem and on other species.

\section{MATERIALS AND METHODS}

Study area. The study was conducted in 2007 and 2008 in the Tarn River $\left(15400 \mathrm{~km}^{2}\right.$ drainage area), a tributary of the Garonne River, in the locality of Villemur-sur-Tarn $\left(43^{\circ} 52^{\prime} \mathrm{N}, 1^{\circ} 30^{\prime} \mathrm{E}\right.$, southwestern France). The studied stretch, located between 2 impassable weirs, was $\sim 8 \mathrm{~km}$ long. The mean discharge was $\sim 145 \mathrm{~m}^{3} \mathrm{~s}^{-1}$, ranging annually from 33 to $267 \mathrm{~m}^{3} \mathrm{~s}^{-1}$. The mean width of the studied stretch was $\sim 81 \mathrm{~m}$, with a mean depth of $3.6 \mathrm{~m}$ (maximum depth of $9 \mathrm{~m}$ ). The catfish was introduced to the Tarn River in 1983. The species has been present in the study stretch since 1987, and a self-sustaining population has now been established. The Tarn River fish assemblage was composed of 24 other species, including 9 non-native species. Three cyprinid fishes dominated the fish community: bleak Alburnus alburnus L., roach $R u$ tilus rutilus (L.) and bream Abramis brama (L.). Other predatory fish included 3 native species: pike Esox lucius L., perch Perca fluviatilis L. and European eel Anguilla anguilla L.; and 2 non-native species: largemouth bass Micropterus salmoides Lacepède and pikeperch Sander lucioperca (L.).

Sample collection. Stomach contents and SIA samples of catfish were collected from local recreational anglers. Fishing was done using a reel and rod, and most fish were caught at dusk. Samples for SIA were collected from mid-April to the end of June both years, which corresponds to the most intensive feeding and growth periods of catfish (Orlova \& Popova 1976, Copp et al. 2009). Stomach contents were collected over a similar period, with additional samples being collected in August and September 2008 to increase the sample size. SIA samples of other predatory fish species and of the most abundant potential prey fish for catfish were also collected. In addition, the mussels Dreissena sp. and Corbicula sp., spinycheek crayfish Orconectes limosus Rafinesque, red swamp crawfish Procambarus clarkii Girard, edible frog Rana esculenta L., pigeon Columbia livia Gmelin and coypu Myocastor coypus Molina were collected from local angling and hunting societies to represent other potential prey which have been previously reported to be consumed by catfish (Orlova \& Popova 1976, Carol et al. 2009, Copp et al. 2009). Mussels were also used as $\delta^{15} \mathrm{~N}$ baseline indicators for calculating trophic positions of species further up the food chain following Vander Zanden et al. (1997). Total length (TL, mm) was recorded from all fish, and a sample of white muscle tissue was dissected for SIA from prey organisms (posterior to the dorsal fin in fish). Small samples of fin tissue were collected from larger predatory fish as recreational anglers typically catch and release these predatory species. Fin clipping was selected because stable isotope values of fins are known to correlate closely with those of muscle tissue 
in small salmonids and other small fish, allowing a non-lethal sampling for SIA (Jardine et al. 2005, Kelly et al. 2006, Sanderson et al. 2009). However, the validity of fin tissue as a proxy for muscle tissue for much larger fish, such as catfish, has not been previously tested. Larger-sized fins may contain greater proportions of bone material, leading to increases in inorganic carbon, thereby potentially affecting the $\delta^{13} \mathrm{C}$ values of fin samples and fin-muscle comparisons. Therefore, we collected additional fin and muscle samples of catfish from 3 other locations (Loire River in western France, Camargue [Rhône delta area] in southern France and a local fish hatchery) to compare $\delta^{13} \mathrm{C}$ and $\delta^{15} \mathrm{~N}$ values between muscle and fin tissue in 28 individuals ( $\mathrm{TL}=60$ to $1340 \mathrm{~mm}$ ).

Stable isotope and data analyses. Stable isotopes, especially those of carbon and nitrogen, are used to examine consumers' trophic ecology from small tissue samples, providing a time-integrated measure of trophic position and energy sources. Stable carbon and nitrogen isotope ratios in consumer tissues reflect those in their diet (Peterson \& Fry 1987), depending on the relative proportions of prey species assimilated over a long time period. Nitrogen stable isotope ratios $\left({ }^{15} \mathrm{~N} /{ }^{14} \mathrm{~N}\right.$, expressed relative to a standard as $\delta^{15} \mathrm{~N}$, in parts per thousand) in consumers are typically enriched in the heavier $\left({ }^{15} \mathrm{~N}\right)$ isotope by from 2 to $4 \%$ per trophic level (Minagawa \& Wada 1984, Peterson \& Fry 1987), making $\delta^{15} \mathrm{~N}$ values useful in defining trophic positions of consumers. The carbon isotope ratios $\left({ }^{13} \mathrm{C} /{ }^{12} \mathrm{C}, \delta^{13} \mathrm{C}\right.$, in parts per thousand) fractionate to a lesser extent ( 0 to $1 \%$ ) and are typically used to define diet compositions or sources of energy (primary production). All samples for SIA were oven dried $\left(60^{\circ} \mathrm{C}\right.$ for $48 \mathrm{~h}$ ) and ground into a fine homogeneous powder using a mixer mill (Retsch MM 200). Approximately $0.2 \mathrm{mg}$ of sample was accurately weighed into small tin cups, and stable isotope ratios of carbon and nitrogen were analysed in a Carlo Erba NC2500 elemental analyser coupled to a Thermo Finnigan Mat Delta XP isotope ratio mass spectrometer. Isotope ratios are reported in delta notation as per international standards: Peedee belemnite carbonate for $\delta^{13} \mathrm{C}$ and atmospheric nitrogen for $\delta^{15} \mathrm{~N}$. Data were corrected using working standards (bass muscle, bovine liver, nicotinamide; $\mathrm{SD}<0.2 \%$ for both $\delta^{13} \mathrm{C}$ and $\delta^{15} \mathrm{~N}$ ) that were previously calibrated against International Atomic Energy Agency (IAEA) standards. All stable isotope analyses were performed at the Stable Isotopes in Nature Laboratory, University of New Brunswick, Canada.

Linear regression and paired $t$-tests were used to examine differences between muscle and fin $\delta^{13} \mathrm{C}$ and $\delta^{15} \mathrm{~N}$ values. In addition, linear regression analysis was also applied to examine potential ontogenetic shifts in catfish by comparing $\delta^{13} \mathrm{C}$ and $\delta^{15} \mathrm{~N}$ values and TL of individuals. Trophic positions (TP) for all prey and predatory fish were calculated following Vander Zanden et al. (1997): TP $=\left(\delta^{15} N_{\text {fish }}-\delta^{15} N_{\text {mussel }} / \Delta\right)+2$, where $\Delta$ is the trophic fractionation factor for $\delta^{15} \mathrm{~N}$ values and 2 is the trophic position for mussels. Considerable variation exists in the literature around the mean trophic fractionation for $\delta^{15} \mathrm{~N}$ (e.g. Martinez del Rio et al. 2009), the most often used values being between 2.8 and $3.4 \%$. We used a $\Delta$ value of $+3 \%$, and using any value within the proposed range would not dramatically affect the conclusions drawn, when comparing organisms within the same food web. Catfish were also grouped into 3 main categories according to their TL; small-bodied $(<600 \mathrm{~mm})$ and medium-bodied (600 to $1300 \mathrm{~mm}$ ) individuals that correspond to typical body sizes of the other piscivorous fish species, whereas large-bodied catfish (>1300 $\mathrm{mm}$ ) correspond to sizes not reached by any other fish species in the study area. Differences in mean isotope values and trophic positions between catfish size categories and pike and pikeperch (principal top predators within the system) were examined using analysis of variance (ANOVA) followed by Tukey's multiple comparisons. All statistical analyses were performed using SPSS for Windows 13.0 software package (SPSS, Inc.).

\section{RESULTS}

Altogether, 49 individuals of catfish Silurus glanis were caught and sampled for SIA from the Tarn River. Eighteen of these were categorised as small bodied ranging in TL from 200 to $580 \mathrm{~mm}$, whereas 15 individuals were categorised as medium bodied (600 to $1300 \mathrm{~mm}$ ) and 16 individuals as large bodied (1400 to $2240 \mathrm{~mm}$; Table 1). One juvenile (60 mm) catfish was

Table 1. Mean \pm SE total length (TL), minimum and maximum length, and mean \pm SE trophic position (TP) for catfish Silurus glanis and each analysed fish species from the Tarn River

\begin{tabular}{|lrccc|}
\hline Species & $\mathrm{n}$ & $\mathrm{TL}(\mathrm{mm})$ & $\begin{array}{c}\text { TL }(\mathrm{min} . / \\
\text { max., mm) }\end{array}$ & TP \\
\hline European catfish & 49 & $1000 \pm 85$ & $200 / 2240$ & $4.5 \pm 0.0$ \\
$\quad$ Small bodied & 18 & $401 \pm 27$ & $200 / 580$ & $4.3 \pm 0.1$ \\
$\quad$ Medium bodied & 15 & $946 \pm 68$ & $600 / 1300$ & $4.5 \pm 0.0$ \\
$\quad$ Large bodied & 16 & $1724 \pm 65$ & $1400 / 2240$ & $4.7 \pm 0.1$ \\
Crayfish & 7 & - & & $3.0 \pm 0.1$ \\
Bleak & 9 & $101 \pm 3.4$ & $85 / 108$ & $3.4 \pm 0.1$ \\
Common bream & 15 & $159 \pm 9.6$ & $110 / 220$ & $3.7 \pm 0.0$ \\
Roach & 9 & $143 \pm 14$ & $110 / 210$ & $3.6 \pm 0.0$ \\
European eel & 5 & $418 \pm 68$ & $230 / 640$ & $4.2 \pm 0.1$ \\
Largemouth bass & 3 & $213 \pm 8.8$ & $200 / 230$ & $4.2 \pm 0.1$ \\
Pike & 8 & $654 \pm 42$ & $500 / 770$ & $4.5 \pm 0.1$ \\
Pikeperch & 11 & $643 \pm 17$ & $550 / 750$ & $5.1 \pm 0.0$ \\
\hline
\end{tabular}


also caught and analysed for stable isotopes, but was not categorised, or used in any of the statistical analyses. Although nearly 100 individual catfish were sampled for stomach contents by the local anglers, only 31 had prey in their stomach. Among these individuals, cyprinid fish species were the most frequently observed prey in all catfish size classes, whereas molluscs and crayfish became less frequent, and terrestrial prey became more frequent in large-bodied individuals (Table 2).

Both $\delta^{13} \mathrm{C}$ and $\delta^{15} \mathrm{~N}$ values between catfish muscle and fin tissues were highly correlated and consistent along the range of analysed isotope values, and the values did not differ between the 2 tissue types (Fig. 1). The mean $\pm \mathrm{SE}$ value of $\delta^{13} \mathrm{C}$ fin tissues was only slightly elevated compared to muscle tissue $\left(+0.27 \pm 0.2 \%\right.$, paired $t$-test: $\left.t_{27}=-1.45, \mathrm{p}=0.158\right)$, whereas the mean $\delta^{15} \mathrm{~N}$ value was $0.09 \pm 0.1 \%$ lower in fin tissue compared to muscle (paired $t$-test: $t_{27}=$ $-0.76, p=0.457$ ). Since no difference was found between catfish fin and muscle tissue $\delta^{13} \mathrm{C}$ and $\delta^{15} \mathrm{~N}$ values and the values were highly correlated, we did not make any correction on the catfish fin tissue $\delta$-values for comparison with muscle tissue of other food web components.

A clear relationship was found between catfish TL and both $\delta^{13} \mathrm{C}$ and $\delta^{15} \mathrm{~N}$ values (Fig. 2), with larger individuals being both significantly ${ }^{13} \mathrm{C}$ and ${ }^{15} \mathrm{~N}$ enriched $\left(F_{1,48}=55.8, \mathrm{p}<0.001, \mathrm{r}^{2}=0.54\right.$ for $\delta^{13} \mathrm{C}$ and $F_{1,48}=19.5, \mathrm{p}<0.001, \mathrm{r}^{2}=0.29$ for $\left.\delta^{15} \mathrm{~N}\right)$. The $\delta^{13} \mathrm{C}$ values increased rather consistently along the range of $\mathrm{TL}$, whereas the increase in $\delta^{15} \mathrm{~N}$ values with catfish TL was more modest and accompanied with considerable variation. The same was evident in the trophic positions of catfish, which changed only slightly, albeit significantly, from small-bodied individuals to medium- and large-bodied individuals (Table 1). Medium- and large-bodied individuals had significantly elevated trophic positions compared to small-
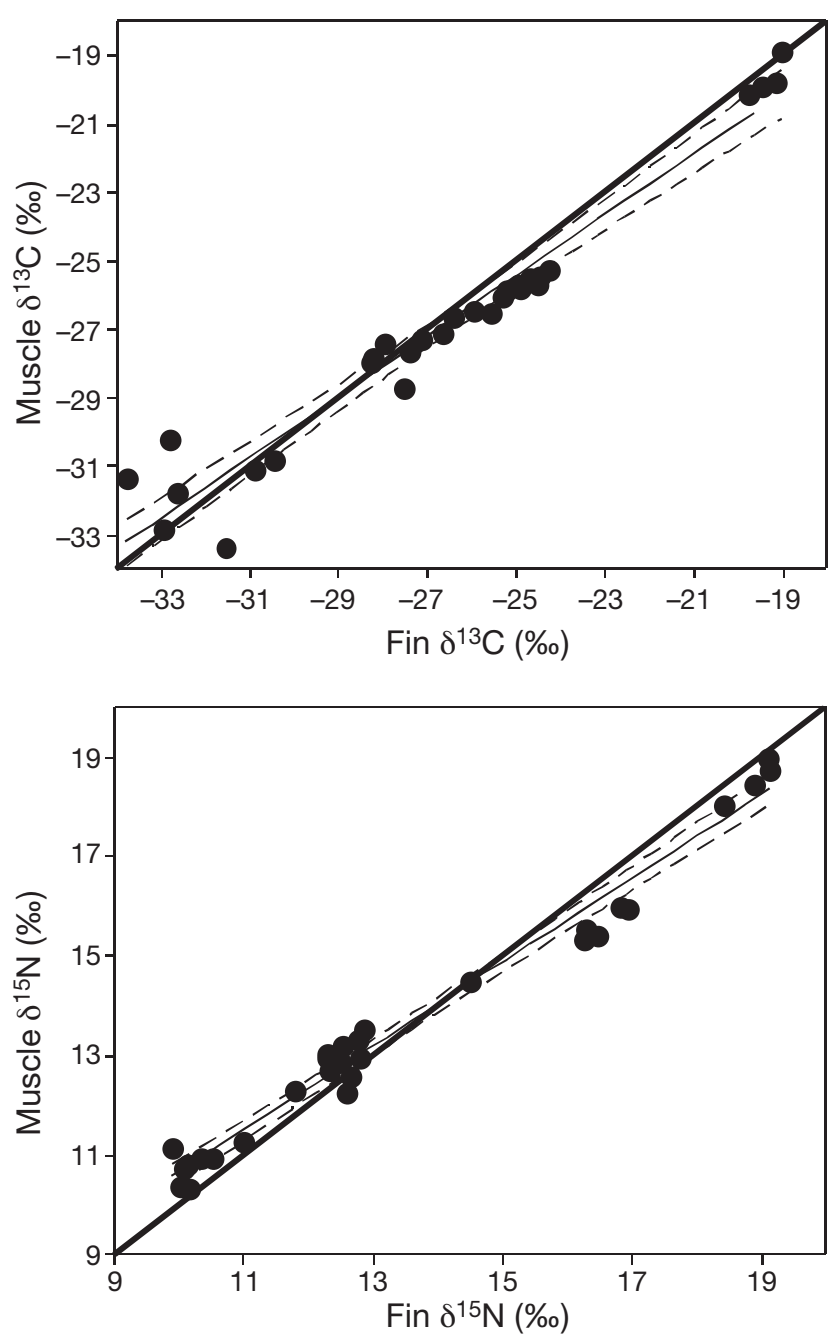

Fig. 1. Silurus glanis. Comparisons of $\delta^{13} \mathrm{C}$ (upper panel) and $\delta^{15} \mathrm{~N}$ (lower panel) values between European catfish fin and muscle tissues. Solid thin lines indicate the fitted regressions $\left(\delta^{13} \mathrm{C}: y=0.89 x-3.24, \mathrm{r}^{2}=0.95, \mathrm{n}=28 ; \delta^{15} \mathrm{~N}: y=0.84 x+2.19\right.$, $\mathrm{r}^{2}=0.98, \mathrm{n}=28$ ) and dashed lines indicate $95 \%$ confidence limits. The thick solid lines indicate a 1:1 fit
Table 2. Silurus glanis. Frequency of occurrence (\%) of different prey in the stomach contents of European catfish from the Tarn River, which are categorized into 3 size groups based on their total length. n: number of individuals found with prey in their stomach for each size category

\begin{tabular}{|lccc|}
\hline \multirow{2}{*}{ Prey } & \multicolumn{3}{c|}{ Catfish size category } \\
\cline { 2 - 4 } & $<600 \mathrm{~mm}$ & 30 & $>1300 \mathrm{~mm}$ \\
\hline Molluscs & 40 & 30 & 0 \\
Crustaceans & 20 & 40 & 10 \\
Cyprinids & 60 & 0 & 90 \\
Amphibians & 0 & 10 & 0 \\
Birds & 0 & 0 & 10 \\
Mammals & 0 & 9 & 10 \\
$\mathrm{n}$ & 5 & & 17 \\
\hline
\end{tabular}

bodied individuals $\left(F_{2,48}=10.2, \mathrm{p}<\right.$ 0.001 ), but did not differ between each other. The trophic position of pike did not differ from those of any catfish size category, whereas pikeperch had a significantly ( $p<0.001$ ) elevated trophic position compared to pike and all catfish sizes.

The $\delta^{13} \mathrm{C}$ values of all individual catfish (excluding the juvenile individual) ranged by a value of $5.1 \%$ (from -27.2 to $-22.1 \%$ ), while those of small-bodied individuals ranged by $3.4 \%$ ( -26.5 to $-23.1 \%$ ), by $4.0 \%$ for medium-bodied 

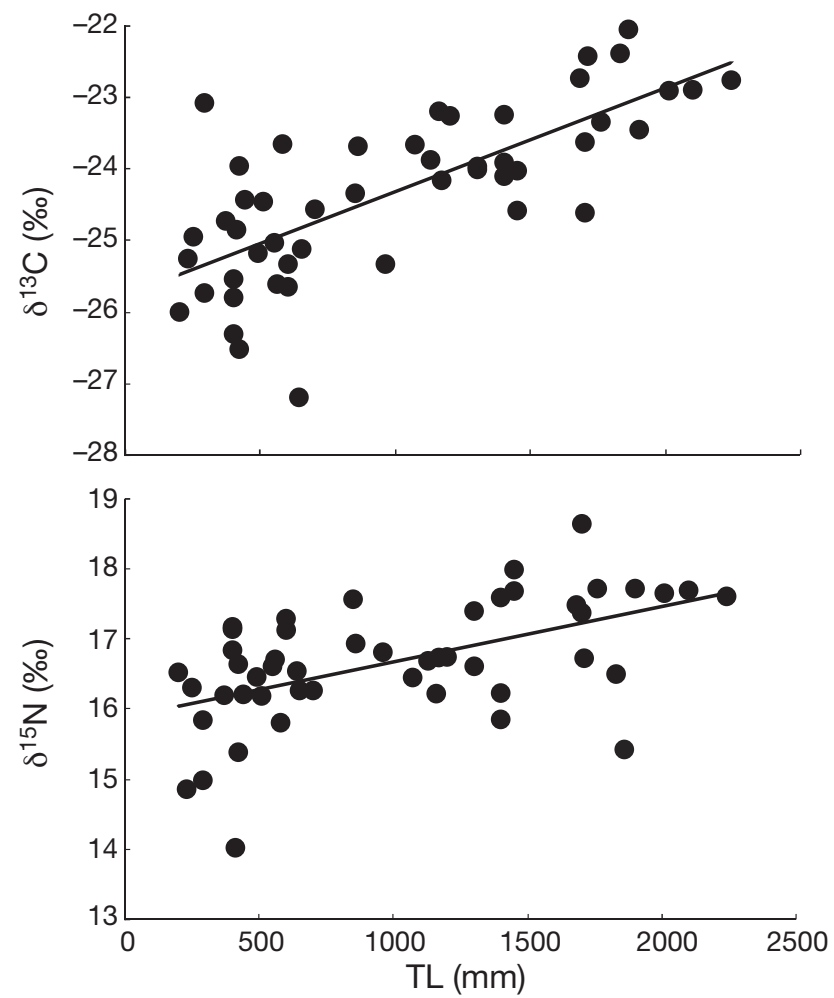

Fig. 2. Silurus glanis. Relationships between European catfish total length (TL) and $\delta^{13} \mathrm{C}$ (upper panel) and $\delta^{15} \mathrm{~N}$ (lower panel) values. Solid lines indicate fitted regressions $\left(\delta^{13} \mathrm{C}: y=0.001 x-\right.$ $25.8, \mathrm{r}^{2}=0.54, \mathrm{n}=49 ; \delta^{15} \mathrm{~N}: y=0.001 x+15.9, \mathrm{r}^{2}=0.29, \mathrm{n}=49$ ) individuals ( -27.2 to $-23.2 \%$ ) and by $2.5 \%$ for largebodied individuals (-24.6 to $-22.1 \%$; Fig. 3). Similarly, the $\delta^{15} \mathrm{~N}$ values for all individuals ranged by $4.7 \%$ o $(14.0$ to $18.7 \%$ ); those of small-bodied individuals by $3.2 \%$ (14.0 to $17.2 \%$ ), by $1.4 \%$ or medium-bodied (16.2 to $17.6 \%$ ) and by $3.3 \%$ ( 15.4 to $18.7 \%$ ) for large-bodied individuals. The 3 TL groups of catfish differed significantly in their mean $\delta^{13} \mathrm{C}$ and $\delta^{15} \mathrm{~N}$ values $\left(F_{2,48}=15.46\right.$, $\mathrm{p}<0.001$ for $\delta^{13} \mathrm{C}$ and $F_{2,48}=10.17, \mathrm{p}<0.001$ for $\left.\delta^{15} \mathrm{~N}\right)$. Large-bodied catfish had a mean $\pm \mathrm{SE} \delta^{13} \mathrm{C}$ value of $-23.3 \pm 0.2 \%$, which was significantly enriched relative to the mean values of both small-bodied $(-25.1 \pm$ $0.2 \%$ ) and medium-bodied individuals ( $-24.5 \pm 0.3 \%$ o) In contrast, the mean $\pm \mathrm{SE} \delta^{15} \mathrm{~N}$ value of small-bodied catfish $(16.1 \pm 0.2 \%$ o) was significantly lower than those of medium-bodied (16.8 $\pm 0.1 \%$ o) and large-bodied $(17.3 \pm 0.2 \%$ o individuals.

Most catfish individuals, except the juvenile one, had $\delta^{15} \mathrm{~N}$ values consistently 2 to $4 \%$ higher than their putative prey sources. In contrast, the juvenile catfish individual had a $\delta^{15} \mathrm{~N}$ value $\sim 6 \%$ lower than most larger catfish (Fig. 3). The $\delta^{13} \mathrm{C}$ values of most smalland medium-bodied catfish were in accordance with their principal aquatic prey, as indicated by the stomach contents. However, larger catfish individuals were considerably ${ }^{13} \mathrm{C}$-elevated (up to $4 \%$ higher $\delta^{13} \mathrm{C}$ values) than their expected fish prey.

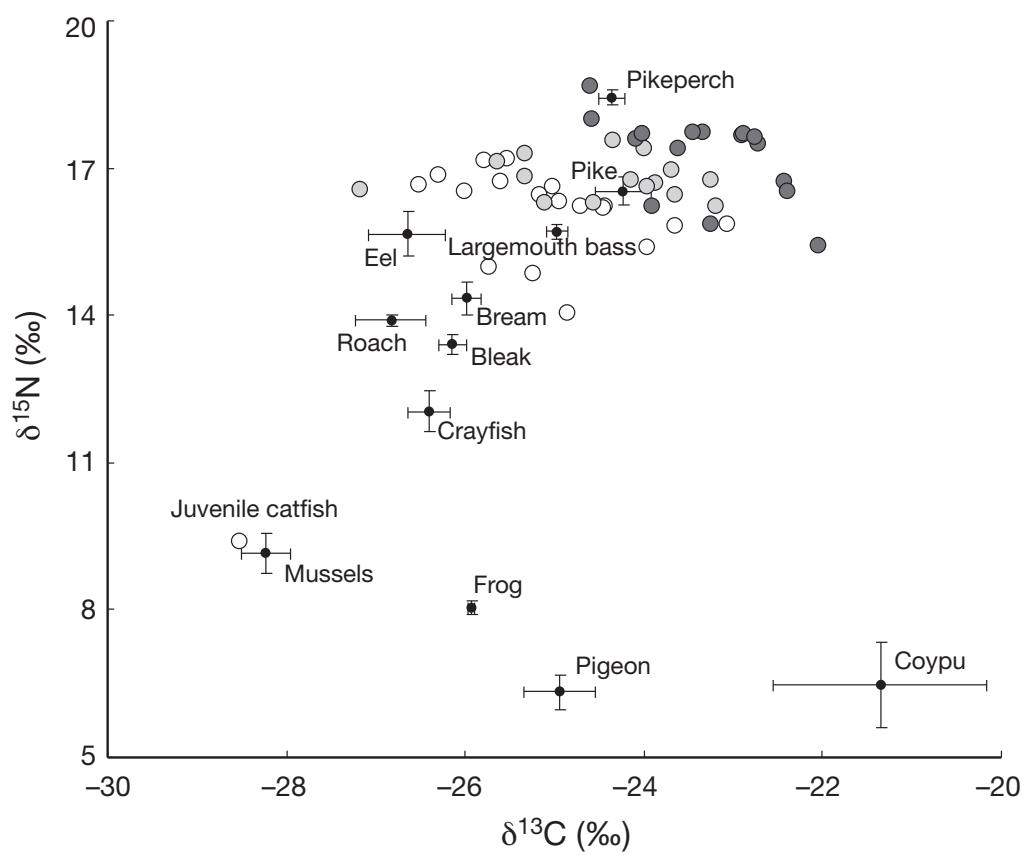

Fig. 3. $\delta^{13} \mathrm{C}$ and $\delta^{15} \mathrm{~N}$ biplot of the Tarn River food web. Mean values $( \pm \mathrm{SE})$ are given for all other species except European catfish Silurus glanis, for which individual values are given. Open symbols: small-bodied individuals; closed light grey symbols: medium-bodied individuals; closed dark grey symbols: large-bodied individuals. A single analysed juvenile catfish $(60 \mathrm{~mm})$ is also separately indicated

\section{DISCUSSION}

Stomach contents of catfish Silurus glanis from the Tarn River indicated a dominance of cyprinid fishes and benthic prey (molluscs and crayfish) in their diet, particularly in the smaller size groups. These are also the commonly reported prey items for catfish in the literature (e.g. Carol et al. 2009, Copp et al. 2009). However, sampling for catfish stomach contents revealed the often encountered difficulty with primarily piscivorous fish. High frequency of empty stomachs is particularly troublesome when studying fish species that are difficult to capture (e.g. low density, inaccessible habitats) and handle (e.g. endangered, large body size), and are also preferably released alive after capture. This fact highlights the need for alternative methods to study the trophic ecology of large-bodied predators, especially methods that allow nonlethal sampling. Samples from the Tarn River were caught by local anglers, 
who, after measuring TL and collecting a small fin clip, released all individuals into the river. Fin and muscle tissue $\delta^{13} \mathrm{C}$ and $\delta^{15} \mathrm{~N}$ comparisons in salmonids and sculpins have produced consistent relationships (Jardine et al. 2005, Kelly et al. 2006, Sanderson et al. 2009), thereby enabling the use of fin tissue as a proxy for muscle tissue. However, not much has been published on larger fish species or on anything even remotely similar to catfish. Therefore, it was necessary to test if the fin samples from catfish could be used in SIA with confidence. Our results clearly indicate that the values analysed from fin tissues provide a suitable alternative for muscle tissue from catfish and can be used to study the trophic ecology of catfish. The size of catfish did not affect the fin-muscle comparisons. While the mean $\delta^{13} \mathrm{C}$ and $\delta^{15} \mathrm{~N}$ values between fin and muscle tissue were not significantly different, muscle had a tendency for lower $\delta^{13} \mathrm{C}$ and higher $\delta^{15} \mathrm{~N}$ values, as also reported by Sanderson et al. (2009).

Comparisons of catfish TL and stable isotope values revealed significant size-related relationships (Fig. 2). $\delta^{13} \mathrm{C}$ values in particular increased consistently with catfish TL, indicating a gradual shift in diet composition with increasing size (and age). Although the $\delta^{15} \mathrm{~N}$ values and TL of catfish were positively correlated, the $\delta^{15} \mathrm{~N}$ values and, hence, TP only slightly increased during ontogeny. The mean difference in $\delta^{15} \mathrm{~N}$ values between the smallest and largest size groups was only $1.2 \%$. Although statistically significant, this translates only to $<0.5$ trophic levels (Table 1 ). Such subtle changes in $\delta^{15} \mathrm{~N}$ values can be further masked behind the potential inherent variability in stable isotope values (Barnes et al. 2008). It is also possible that $\delta^{15} \mathrm{~N}$ values increase along increasing animal age irrespective of diet (Minagawa \& Wada 1984, Overman \& Parrish 2001), and the largest catfish in our samples are likely to be very old ( $>20 \mathrm{yr}$ ). However, the $\delta^{13} \mathrm{C}$ values also indicated a change in diet composition that could partly explain the slight change in $\delta^{15} \mathrm{~N}$ values, albeit no meaningful ontogenetic changes in trophic position were evident. The 1 juvenile catfish $(60 \mathrm{~mm})$ in our samples differed substantially from all other catfish samples in both $\delta^{15} \mathrm{~N}$ and $\delta^{13} \mathrm{C}$, suggesting that any notable ontogenetic shift occurs within the gap in our size range (60 to $200 \mathrm{~mm}$ ). The $\delta^{13} \mathrm{C}$ values measured from Tarn River catfish spanned over 5\%, indicating both considerable individual-level differences in diet composition (Syväranta \& Jones 2008) and a wide use of available resources (Fig. 3). This is consistent with the conclusions of Copp et al. (2009) who stated that the dietary spectrum of catfish is considerably greater than that for many other piscivorous fish, such as pike or pikeperch.

Catfish did occupy a trophic position typical of piscivorous fish and equal to that of pike (Table 1), al- though significantly lower than the trophic position of the non-native pikeperch as also reported by Kopp et al. (2009). However, the variation observed in catfish $\delta^{13} \mathrm{C}$ values was considerably higher than that for pike or pikeperch, suggesting that catfish is a much more flexible predator in terms of diet than the 2 other top predators in this ecosystem. This would also indicate that catfish does not have a fixed role as an efficient top predator in the food web and is perhaps unlikely to have any serious adverse impacts on the underlying fish community.

Trophic position is often expected to increase from smaller-bodied species to larger-bodied ones (e.g. Cohen et al. 1993, Roy et al. 2002, Woodward et al. 2005). Similarly, one might expect the trophic position to increase within a single predatory species during ontogeny, especially if body size increases as considerably as in catfish. Such increases in trophic position could result from changes in (feeding) behaviour and increased gape size, allowing the consumption of larger prey from potentially higher trophic levels. Therefore, it is perhaps surprising that catfish in the Tarn River reflected only negligible changes in trophic position with increasing body size. However, catfish are known to prey upon fish considerably smaller than what could be expected based on their gape size (Wysujack \& Mehner 2005), and they are also considered an opportunistic species (Copp et al. 2009). This can actually mean that their diet composition is not expected to go through very drastic changes according to increasing body size for the larger individuals, at least in terms of feeding from higher trophic levels, which is consistent with the present results.

The $\delta^{13} \mathrm{C}$ values of large-bodied catfish were heavily enriched compared to those of most of the smaller individuals and to those of any analysed aquatic prey item, reflecting a significant dietary contribution from a relatively ${ }^{13} \mathrm{C}$-enriched source. Such elevated $\delta^{13} \mathrm{C}$ values were only analysed from pigeons and coypu, but the $\delta^{15} \mathrm{~N}$ values of this prey source were considerably lower than those in any other prey source and $10 \%$ lower than the $\delta^{15} \mathrm{~N}$ values of catfish. Therefore, any catfish heavily relying on this prey source ought to show corresponding decrease in $\delta^{15} \mathrm{~N}$ values, which was not evident. Catfish are known to feed on many anadromous species, which would reflect marine $\delta^{13} \mathrm{C}$ values when migrating from marine to freshwater habitats, and feeding on prey with such distinct $\delta^{13} \mathrm{C}$ values can quickly elevate the $\delta^{13} \mathrm{C}$ values of catfish (MacAvoy et al. 2000, Syväranta et al. 2009). But migrations of anadromous fish are effectively prevented by damming in the Tarn River, so any dietary contribution from anadromous fish with elevated $\delta^{13} \mathrm{C}$ values is unlikely. Some terrestrial vertebrates, mainly birds and small mammals, are known to contribute to 
the diets of catfish (Copp et al. 2009). These items were also observed in the stomach contents of large-bodied catfish in our study (Table 2), and catfish in the Tarn River are frequently seen catching pigeons from rocks in the river. However, comprehensive sampling of this prey source is not always straightforward, and, hence, our stable isotope samples of potential terrestrial prey for catfish consisted only of 3 pigeons and 3 coypu. Therefore, it is possible that the inconsistency between the $\delta^{13} \mathrm{C}$ and especially $\delta^{15} \mathrm{~N}$ values between the larger catfish and their prey may result from insufficient sampling of terrestrial prey sources and potentially biased estimates for the $\delta^{15} \mathrm{~N}$ values.

In conclusion, the combined use of stomach contents and SIA provided new insights into the trophic ecology of catfish outside of its native range. Our first original objective was to assess the suitability of fin clips as a proxy for muscle tissue, and our results clearly indicate that fin clips provide a suitable and non-lethal proxy for muscle tissue in SIA. Also, we aimed to assess the trophic positions and ontogenetic changes in trophic ecology of catfish in the Tarn River using both SIA from fin clips and gut contents. While the changes in trophic position with increasing size were rather small in the size range we studied, we demonstrated that the ontogenic changes in body size may still be associated with a shift towards a prey less exploited by other predators. This mechanism might facilitate the establishment of this non-native species outside its native range, as it might reduce both intraspecific and interspecific competition by providing a partly vacant niche for larger catfish. In conclusion to our third objective, our results also indicate that catfish in the Tarn River ecosystem is unlikely a voracious top predator, having strong adverse impact on the native fish community, but rather a scavenging predator able to exploit a wide variety of prey sources. However, future studies should determine in greater detail whether this might alter the structure and function of the food web by comparing similar ecosystems were the species is absent and present.

Acknowledgements. Local fishing and hunting societies are thanked for providing us with many samples. Three anonymous reviewers are thanked for their valuable comments on an earlier version of this manuscript. J.S. and D.K. were supported by the CNRS and Region Midi-Pyrénées post-doctoral fellowships.

\section{LITERATURE CITED}

Barnes C, Jennings S, Polunin NVC, Lancaster JE (2008) The importance of quantifying inherent variability when interpreting stable isotope field data. Oecologia 155:227-235

Carol J (2007) Ecology of an invasive fish (Silurus glanis) in Catalan reservoirs. PhD dissertation, University of Girona, Girona
Carol J, Benejam L, Benito J, García-Berthou E (2009) Growth and diet of European catfish (Silurus glanis) in early and late invasion stages. Fundam Appl Limnol 174:317-328

Cohen JE, Pimm SL, Yodzis P, Saldana J (1993) Body sizes of animal predators and animal prey in food webs. J Anim Ecol 62:67-78

Copp GH, Bianco PG, Bogutskaya NG, Erős T and others (2005) To be, or not to be, a non-native freshwater fish? J Appl Ichthyol 21:242-262

Copp GH, Britton R, Cucherousset J, García-Berthou E, Kirk R, Peeler E, Stakènas S (2009) Voracious invader or benign feline? A review of the environmental biology of European catfish Silurus glanis in its native and introduced ranges. Fish Fish 10:252-282

Cucherousset J, Aymes JC, Santoul F, Céréghino R (2007) Stable isotope evidence of trophic interactions between introduced brook trout (Salvelinus fontinalis) and native brown trout (Salmo trutta) in a mountain stream of southwest France. J Fish Biol 71(Suppl D):210-223

> Dudgeon D, Arthington AH, Gessner MO, Kawabata ZI and others (2006) Freshwater biodiversity: importance, threats, status and conservation challenges. Biol Rev Camb Philos Soc 81:163-182

Eby LA, Roach WJ, Crowder LB, Stanford JA (2006) Effects of stocking-up freshwater food webs. Trends Ecol Evol 21: 576-584

> Forsman A (1996) Body size and net energy gain in gapelimited predators: a model. J Herpetol 30:307-319

> Gorokhova E, Hansson S, Höglander H, Andersen CM (2005) Stable isotopes show food web changes after invasion by the predatory cladoceran Cercopagis pengoi in a Baltic Sea bay. Oecologia 143:251-259

Jardine TD, Gray MA, McWilliam SM, Cunjak RA (2005) Stable isotope variability in tissues of stream fishes. Trans Am Fish Soc 134:1103-1110

- Kelly MH, Hagar WG, Jardine TD, Cunjak RA (2006) Nonlethal sampling of sunfish and slimy sculpin for stable isotope analysis: how scale and fin tissue compare with muscle tissue. N Am J Fish Manage 26:921-925

Kopp D, Cucherousset J, Syväranta J, Martino A, Céréghino R, Santoul F (2009) Trophic ecology of the pikeperch (Sander lucioperca) in its introduced areas: a stable isotope approach in southwestern France. C R Biol 332: 741-746

Layman CA, Winemiller KO, Arrington DA, Jepsen DB (2005) Body size and trophic position in a diverse tropical food web. Ecology 86:2530-2535

> MacAvoy SE, Macko SA, McIninch SP, Garman GC (2000) Marine nutrient contributions to freshwater apex predators. Oecologia 122:568-573

Martinez del Rio C, Wolf N, Carleton SA, Gannes LZ (2009) Isotopic ecology ten years after a call for more laboratory experiments. Biol Rev Camb Philos Soc 84:91-111

Minagawa M, Wada E (1984) Stepwise enrichment of ${ }^{15} \mathrm{~N}$ along food chains: further evidence and the relation between $\delta^{15} \mathrm{~N}$ and animal age. Geochim Cosmochim Acta 48:1135-1140

> Olsson K, Stenroth P, Nyström P, Graneli W (2009) Invasions and niche width: Does niche width of an introduced crayfish differ from a native crayfish? Freshw Biol 54:1731-1740

Orlova EL, Popova OA (1976) The feeding of predatory fish, the sheatfish, Silurus glanis, and the pike, Esox lucius, in the Volga Delta following regulation of the discharge of the river. J Ichthyol 16:75-87

Overman NC, Parrish DL (2001) Stable isotope composition of walleye: ${ }^{15} \mathrm{~N}$ accumulation with age and area-specific differences in $\delta^{13} \mathrm{C}$. Can J Fish Aquat Sci 58:1253-1260 
Peterson BJ, Fry B (1987) Stable isotopes in ecosystem studies. Annu Rev Ecol Syst 18:293-320

Roy K, Jablonski D, Valentine JW (2002) Body size and invasion success in marine bivalves. Ecol Lett 5:163-167

Sanderson BL, Coe HJ, Pelekis V, Steel EA, Reichert WL (2009) Nonlethal sampling of fish caudal fins yields valuable stable isotope data for threatened and endangered fishes. Trans Am Fish Soc 138:1166-1177

Stone R (2007) The last of the Leviathans. Science 316: 1684-1688

Syväranta J, Jones RI (2008) Changes in feeding niche widths of perch and roach following biomanipulation, revealed by stable isotope analysis. Freshw Biol 53:425-434

Syväranta J, Cucherousset J, Kopp D, Martino A, Céréghino R, Santoul F (2009) Contribution of anadromous fish to the diet of European catfish in a large river system. Naturwissenschaften 96:631-635

Editorial responsibility: Asbjørn Vøllestad, Oslo, Norway
Vander Zanden MJ, Cabana G, Rasmussen JB (1997) Comparing trophic position of freshwater fish calculated using stable nitrogen isotope ratios $\left(\delta^{15} \mathrm{~N}\right)$ and literature dietary data. Can J Fish Aquat Sci 54:1142-1158

Vander Zanden MJ, Casselman JM, Rasmussen JB (1999) Stable isotope evidence for the food web consequences of species invasions in lakes. Nature 401:464-467

Vander Zanden MJ, Olden JD, Thorne JH, Mandrak NE (2004) Predicting occurrences and impacts of smallmouth bass introductions in north temperate lakes. Ecol Appl 14: $132-148$

Woodward G, Ebenman B, Emmerson M, Montoya JM, Olesen JM, Valido A, Warren PH (2005) Body-size in ecological networks. Trends Ecol Evol 20:402-409

Wysujack K, Mehner T (2005) Can feeding of European catfish prevent cyprinids from reaching a size refuge? Ecol Freshwat Fish 14:87-95

Submitted: May 14, 2009; Accepted: December 15, 2009

Proofs received from author(s): January 13, 2010 